\title{
Continuous mixed venous oxygen saturation, not mean blood pressure, is associated with early bupivacaine cardiotoxicity in dogs
}

\author{
[La saturation en oxygène du sang veineux mêlé, mais non la tension artérielle \\ moyenne, est associée à une cardiotoxicité précoce à la bupivacaïne chez les chiens]
}

Jin-Tae Kim MD, Ka-Young Rhee MD, Jae-Hyon Bahk MD, Sang-Hwan Do MD, Young-Jin Lim MD, Hong Ko MD, Kook-Hyun Lee MD

\begin{abstract}
Purpose: To investigate changes of continuous mixed venous oxygen saturation $\left(\mathrm{CSvO}_{2}\right)$ and mean arterial blood pressure (MBP) in dogs with bupivacaine-induced cardiac depression.

Methods: Bupivacaine was infused into pentobarbital-anesthetized mongrel dogs $(n=8)$ at a rate of $0.5 \mathrm{mg} \cdot \mathrm{kg}^{-1} \cdot \mathrm{min}^{-1}$ until the MBP was $40 \mathrm{mmHg}$ or less (end of bupivacaine infusion; BIE). The infusion time was divided into the early period, first $30 \mathrm{~min}$ of bupivacaine infusion and the late period, which was from $30 \mathrm{~min}$ of bupivacaine infusion until $\mathrm{BIE}$. $\mathrm{CSVO}_{2}$ was monitored using a fibreoptic pulmonary artery catheter, and MBP and cardiac output (CO) were measured every ten minutes after the initiation of bupivacaine infusion. Arterial blood gas, serum electrolyte and bupivacaine concentration were measured simultaneously. The relationships between $\mathrm{CO}$ and $\mathrm{CSvO}_{2}$, and of $\mathrm{CO}$ vs MBP were compared by regression analysis in the early and late periods.
\end{abstract}

Results: The Pearson's correlation coefficients between $\mathrm{CO}$ and $\mathrm{CSvO}_{2}$ were $0.782\left(P=2.1 \times 10^{-7}\right)$ in the early period and 0.824 $\left(P=1.3 \times 10^{-6}\right)$ in the late period. The correlation coefficients between $\mathrm{CO}$ and MBP were $0.019(P=0.921)$ in the early period and $0.799\left(P=4.8 \times 10^{-6}\right)$ in the late period.

Conclusions: $\mathrm{CSVO}_{2}$, but not MBP, is associated with $\mathrm{CO}$ changes in bupivacaine-induced cardiac depression during the early period of bupivacaine intoxication. Decrease of MBP with low $\mathrm{CSvO}_{2}$ observed during the late period might imply severe cardiac depression induced by bupivacaine infusion.

\begin{abstract}
Objectif : Examiner les modifications de la saturation continue en oxygène du sang veineux mêlé $\left(\mathrm{S}_{\mathrm{CO}_{2}} \mathrm{v}\right)$ et de la tension artérielle moyenne (TAM) chez des chiens qui présentent une dépression cardiaque induite par la bupivacaïne.

Méthode : La bupivacaine a été administrée chez des chiens de race commune $(n=8)$, anesthésiés au pentobarbital, selon un débit de $0,5 \mathrm{mg} \cdot \mathrm{kg}^{-1} \cdot \mathrm{min}^{-1}$ jusqu'à ce que la TAM soit de $40 \mathrm{mmHg}$ ou moins (fin de la perfusion de bupivacaïne; FPB). Le temps de perfusion a été divisé en une période précoce pour les 30 premières min et tardive, à partir de 30 min jusqu'à la FPB. $\mathrm{La} \mathrm{SCO}_{2} v$ a été enregistrée avec un cathéter artériel pulmonaire fibroscopique. La TAM et le débit cardiaque (DC) ont été mesurés toutes les dix minutes après le début de la perfusion de bupivacaine. La gazométrie du sang artériel, la concentration sérique d'électrolytes et de bupivacaïne ont été mesurées simultanément. La relation entre le $\mathrm{CO}$ et la $\mathrm{ScO}_{2}$, et entre le $\mathrm{CO}$ et la TAM a été comparée par une analyse de régression pendant les deux périodes de perfusion déterminées.
\end{abstract}

Résultats : Les coefficients de corrélation de Pearson entre le $\mathrm{CO}$ et la $\mathrm{ScO}_{2}$ v ont été de $0,782\left(\mathrm{P}=2,1 \times 10^{-7}\right)$ pendant la période précoce de la perfusion et de 0,824 ( $\left.P=1,3 \times 10^{-6}\right)$ pendant la période tardive. Les coefficients de corrélation entre le $\mathrm{CO}$ et la TAM ont été de 0,019 $(P=0,921)$ pendant la période précoce et de 0,799 $\left(P=4,8 \times 10^{-6}\right)$ pendant la période tardive.

Conclusion : $\mathrm{La} \mathrm{SCO}_{2}$, mais non la TAM, est associée aux variations de CO de la dépression cardiaque induite par la bupivacaïne pendant la période précoce de l'intoxication à la bupivacaïne. Une baisse de la TAM, accompagnée d'une faible $\mathrm{ScO}_{2} v$, observée pendant la période tardive, peut correspondre à une dépression cardiaque sévère induite par la perfusion de bupivacaïne.

From the Department of Anesthesiology and Pain Medicine, College of Medicine, Seoul National University, Seoul, Korea. Address correspondence to: Dr. Kook Hyun Lee, Department of Anesthesiology, Seoul National University Hospital, 28 Yongon-Dong, Chongno -Gu, Seoul, Korea 110-774. Phone: 82-2-760-2567, 1720; Fax: 82-2-747-5639; E-mail: leekh@plaza.snu.ac.kr

This article was supported by a grant of the Seoul National University (00-3-3-48). Accepted for publication September 26, 2002.

Revision accepted December 13, 2002. 
B UPIVACAINE can provoke cardiovascular complications such as arrhythmia, hypotension and cardiac arrest when large doses are administered or intravascular injection occurs accidentally. The mechanism of bupivacaineinduced cardiac depression has been associated with the inhibition of cardiac muscle depolarization resulting from the $\mathrm{Na}^{+}$channel block ${ }^{1}$ and the inhibition of repolarization because of the presence of an outward $\mathrm{K}^{+}$current (Ito) block. ${ }^{2}$ Bupivacaine also inhibits calcium release from the sarcoplasmic reticulum ${ }^{3}$ and bupivacaine induced-cardiovascular collapse is resistant to conventional treatment. ${ }^{4,5}$ Therefore, the early recognition of bupivacaine-induced cardiac depression is vital to recovery. Though blood pressure is useful for the evaluation of cardiovascular status during clinical anesthesia, prior studies have shown that blood pressure changes little when bupivacaine is injected. ${ }^{6,7}$ Therefore, we expected that it would be difficult to detect bupivacaine-induced cardiac depression at an early stage by monitoring blood pressure.

Mixed venous oxygen saturation $\left(\mathrm{SvO}_{2}\right)$ is closely related to oxygen consumption $\left(\mathrm{VO}_{2}\right)$ and oxygen delivery $\left(\mathrm{DO}_{2}\right) \cdot \mathrm{VO}_{2}$ is known to be independent of $\mathrm{DO}_{2}$ if the latter is above a critical level. ${ }^{8,9}$ If $\mathrm{VO}_{2}$ is constant under general anesthesia with controlled ventilation, cardiac output $(\mathrm{CO})$ changes can be predicted by continuously monitoring $\mathrm{SvO}_{2}\left(\mathrm{cSvO}_{2}\right) \cdot \mathrm{cSvO}_{2}$ is rarely used in most cases where bupivacaine toxicity is likely to occur, however, epidural anesthesia or analgesia is sometimes recommended for major operations that may require pulmonary artery catheterization. ${ }^{10-14}$

We hypothesized that $\mathrm{cSvO}_{2}$ monitoring would reflect $\mathrm{CO}$ changes induced by bupivacaine infusion better than mean arterial blood pressure (MBP). The purpose of this study was to investigate changes of $\mathrm{cSvO}_{2}$ and MBP when $\mathrm{CO}$ decreases and, ultimately, to compare the correlation between $\mathrm{CO}$ and $\mathrm{cSvO}_{2}$ or $\mathrm{MBP}$ in dogs with bupivacaine-induced cardiac depression.

\section{Methods}

The study received approval from the Animal Care and Use Committee of the Seoul National University College of Medicine. The subjects consisted of eight male mongrel dogs (19-20 kg). Anesthesia was induced with sodium pentobarbital $25 \mathrm{mg} \cdot \mathrm{kg}^{-1}$ iv and maintained with a continuous infusion of $5 \mathrm{mg} \cdot \mathrm{kg}^{-1} \cdot \mathrm{hr}^{-1}$ sodium pentobarbital. The trachea was intubated with an internal diameter 7.0-mm cuffed endotracheal tube. Vecuronium was injected as a bolus of $0.2 \mathrm{mg} \cdot \mathrm{kg}^{-1}$, and this was followed by the administration of $0.02 \mathrm{mg} \cdot \mathrm{kg}^{-1}$ at 30 -min intervals. Mechanical ventilation was performed using a Royal ventilator (Royal Medical Co,
Seoul, Korea) to maintain normocarbia at a fraction of inspired oxygen of 1.0. Normal saline was infused at a rate of $5 \mathrm{~mL} \cdot \mathrm{kg}^{-1} \cdot \mathrm{hr}^{-1}$ throughout the experiment.

Cardiac rhythm and heart rate (HR) were monitored continuously by using standard lead II of the electrocardiograph (ECG). A percutaneous 20G polyvinyl catheter was inserted into the femoral artery to obtain blood samples and to monitor arterial blood pressure. A fibreoptic pulmonary artery catheter (Opticath®, P 7110-EH, Abbott, Chicago, IL, USA) was inserted via the external jugular vein to continuously monitor $\mathrm{cSvO}_{2}$ (Oximerix ${ }^{\circledR} 3$, Abbott, Chicago, IL, USA) and central venous pressure (CVP). CO was measured three times using the thermodilution method at ten-minute intervals and pulmonary capillary wedge pressure (PCWP) was monitored simultaneously. ECG lead II and the femoral arterial pressure were monitored continuously and recorded at tenminute intervals throughout the experiment with a HP Component Monitoring System ${ }^{\mathrm{TM}}$ (HewlettPackard Model 54S, Andover, MA, USA). The PR interval, the QRS duration and the QTc interval were also measured. The QTc interval was calculated using the formula of Van de Water et al., ${ }^{15}$ which is appropriate for a rapid HR: QTc $(\mathrm{msec})=\mathrm{QT}-0.087(\mathrm{RR}$ - 1000). Temperature was maintained at $37^{\circ}-38^{\circ} \mathrm{C}$ using a warming blanket. The dogs were stabilized for $30 \mathrm{~min}$ before the start of the experiment.

After having measured the baseline variables, $0.5 \%$ bupivacaine was administered at a rate of 0.5 $\mathrm{mg} \cdot \mathrm{kg}^{-1} \cdot \mathrm{min}^{-1}$ via a venous catheter. At the same time, sodium bicarbonate was infused at a rate of 2-4 $\mathrm{mEq} \cdot \mathrm{kg}^{-1} \cdot \mathrm{hr}^{-1}$ via another venous catheter to maintain arterial $\mathrm{pH}$ 7.35-7.45. Bupivacaine was infused continuously until the MBP decreased to $40 \mathrm{mmHg}$ or less (BIE: end of bupivacaine infusion). We defined the early period as the first $30 \mathrm{~min}$ of bupivacaine infusion, and the late period as the interval from $30 \mathrm{~min}$ of bupivacaine infusion until BIE (Figure 1). MBP, $\mathrm{HR}, \mathrm{CVP}, \mathrm{PCWP}, \mathrm{CSvO}_{2}$ and $\mathrm{CO}$ were measured every ten minutes until BIE. Systemic vascular resistance (SVR) was calculated using a standard formula with MBP, CVP and $\mathrm{CO}$, whereas $\mathrm{DO}_{2}$ and $\mathrm{VO}_{2}$ were calculated as the products of $\mathrm{CO}$ and arterial oxygen content, and $\mathrm{CO}$ and arterial-venous oxygen content difference, respectively, every ten minutes.

Hemoglobin concentration was measured using a blood sample taken at baseline. Arterial blood samples were obtained for blood gas analysis every ten minutes, and these were also analyzed for serum $\mathrm{Na}^{+}, \mathrm{K}^{+}$, calcium and plasma bupivacaine. In five dogs, pulmonary arterial blood was withdrawn to perform mixed venous blood gas analysis and measurement of $\mathrm{SvO}_{2}$ with $\mathrm{cO}^{-}$ 
TABLE I Changes in hemodynamic variables, oxygen delivery $\left(\mathrm{DO}_{2}\right)$ and oxygen consumption $\left(\mathrm{VO}_{2}\right)$

\begin{tabular}{|c|c|c|c|c|c|c|c|c|}
\hline & $\begin{array}{l}0 \text { min } \\
(\text { Baseline }) \\
(n=8)\end{array}$ & $\begin{array}{l}10 \text { min } \\
(n=8)\end{array}$ & $\begin{array}{l}20 \text { min } \\
(n=8)\end{array}$ & $\begin{array}{l}30 \text { min } \\
(n=8)\end{array}$ & $\begin{array}{l}40 \mathrm{~min} \\
(n=6)\end{array}$ & $\begin{array}{l}50 \mathrm{~min} \\
(n=4)\end{array}$ & $\begin{array}{l}60 \text { min } \\
(n=4)\end{array}$ & $\begin{array}{l}B I E \\
(n=8)\end{array}$ \\
\hline $\mathrm{CSvO}_{2}(\%)$ & $90 \pm 8$ & $82 \pm 12^{*} \dagger$ & $76 \pm 15^{*} \dagger$ & $73 \pm 18^{*}$ & $70 \pm 22$ & $77 \pm 15$ & $62 \pm 15$ & $41 \pm 7^{*}$ \\
\hline $\mathrm{MBP}(\mathrm{mmHg})$ & $110 \pm 13$ & $109 \pm 12$ & $104 \pm 9$ & $101 \pm 19$ & $90 \pm 18$ & $94 \pm 10$ & $74 \pm 17$ & $40^{*}$ \\
\hline $\mathrm{HR}\left(\right.$ beats $\left.\cdot \mathrm{min}^{-1}\right)$ & $125 \pm 29$ & $107 \pm 31^{*} \dagger$ & $107 \pm 16^{*}$ & $104 \pm 16^{*}$ & $100 \pm 19$ & $103 \pm 12$ & $91 \pm 13$ & $70 \pm 8^{*}$ \\
\hline $\mathrm{CVP}(\mathrm{mmHg})$ & $5 \pm 3$ & $5 \pm 2$ & $7 \pm 2$ & $7 \pm 3$ & $7 \pm 2$ & $7 \pm 1$ & $7 \pm 2$ & $8 \pm 3^{*}$ \\
\hline PCWP (mmHg) & $8 \pm 2$ & $11 \pm 2$ & $13 \pm 3^{*}$ & $14 \pm 3^{*}$ & $14 \pm 3$ & $14 \pm 3$ & $15 \pm 3$ & $12 \pm 2^{*}$ \\
\hline $\mathrm{CO}\left(\mathrm{L} \cdot \mathrm{min}^{-1}\right)$ & $3.84 \pm 1.33$ & $2.42 \pm 1.07^{\star} \dagger$ & $2.11 \pm 0.83^{*} \dagger$ & $2.03 \pm 0.88^{*}$ & $1.84 \pm 1.03$ & $2.06 \pm 0.75$ & $1.34 \pm 0.68$ & $0.76 \pm 0.35^{*}$ \\
\hline \multicolumn{9}{|l|}{ SVR } \\
\hline$\left(\right.$ dyn $\left.\cdot \sec \cdot \mathrm{cm}^{-5}\right)$ & $2445 \pm 990$ & $4134 \pm 1977$ & $4233 \pm 1708^{*}$ & $4120 \pm 1438^{*}$ & $3949 \pm 1717$ & $3682 \pm 1249$ & $4709 \pm 2218$ & $3930 \pm 1442^{*}$ \\
\hline $\mathrm{DO}_{2}\left(\mathrm{~mL} \cdot \mathrm{kg}^{-1} \cdot \mathrm{min}^{-1}\right)$ & $24.7 \pm 8.7$ & $15.6 \pm 7.1^{*} \dagger$ & $13.5 \pm 5.2^{*}$ & $12.9 \pm 4.8^{*}$ & $11.5 \pm 6.4$ & $12.7 \pm 5.7$ & $8.1 \pm 3.8$ & $4.8 \pm 1.7^{*}$ \\
\hline $\mathrm{VO}_{2}\left(\mathrm{~mL} \cdot \mathrm{kg}^{-1} \cdot \mathrm{min}^{-1}\right)$ & $3.7 \pm 1.2$ & $3.1 \pm 0.7$ & $3.4 \pm 0.7$ & $3.6 \pm 1.4$ & $2.9 \pm 0.4$ & $3.2 \pm 1.3$ & $3.2 \pm 1.3$ & $3.0 \pm 1.1$ \\
\hline
\end{tabular}

Values are expressed as mean $\pm \mathrm{SD}$. BIE $=$ end of bupivacaine infusion; $\mathrm{MBP}=$ mean arterial blood pressure; $\mathrm{HR}=$ heart rate; $\mathrm{PCWP}=$ pulmonary capillary wedge pressure; $\mathrm{CO}=$ cardiac output; $\mathrm{cSvO}_{2}=$ continuous mixed venous oxygen saturation; $\mathrm{SVR}=$ systemic vascular resistance; $\mathrm{DO}_{2}=$ oxygen delivery; $\mathrm{VO}_{2}=$ oxygen consumption.

The comparisons were omitted when a dog reached BIE, resulting in a number of dogs less than eight $(n=6, n=4)$ and data $(n<4)$ are not presented. ${ }^{*} P<0.05$ vs baseline; $\dagger P<0.05$ vs previous value.

TABLE II Arterial blood gas analysis, plasma electrolytes, bupivacaine concentration and ECG intervals

\begin{tabular}{|c|c|c|c|c|c|c|c|c|}
\hline & $\begin{array}{l}0 \text { min } \\
\text { (Baseline) } \\
(n=8)\end{array}$ & $\begin{array}{l}10 \min \\
(n=8)\end{array}$ & $\begin{array}{l}20 \min \\
(n=8)\end{array}$ & $\begin{array}{l}30 \text { min } \\
(n=8)\end{array}$ & $\begin{array}{l}40 \text { min } \\
(n=6)\end{array}$ & $\begin{array}{l}50 \min \\
(n=4)\end{array}$ & $\begin{array}{l}60 \min \\
(n=4)\end{array}$ & $\begin{array}{l}B I E \\
(n=8)\end{array}$ \\
\hline \multicolumn{9}{|l|}{ Arterial } \\
\hline $\mathrm{pH}$ & $7.39 \pm 0.08$ & $7.43 \pm 0.07$ & $7.44 \pm 0.04$ & $7.44 \pm 0.07$ & $7.40 \pm 0.11$ & $7.45 \pm 0.03$ & $7.42 \pm 0.04$ & $7.43 \pm 0.08$ \\
\hline $\mathrm{PO}_{2}(\mathrm{mmHg})$ & $415 \pm 97$ & $474 \pm 116$ & $532 \pm 46$ & $514 \pm 104$ & $475 \pm 137$ & $553 \pm 31$ & $571 \pm 16$ & $531 \pm 48$ \\
\hline $\mathrm{PCO}_{2}(\mathrm{mmHg})$ & $34 \pm 9$ & $34 \pm 8$ & $35 \pm 7$ & $34 \pm 5$ & $35 \pm 8$ & $31 \pm 3$ & $34 \pm 4$ & $34 \pm 8$ \\
\hline \multicolumn{9}{|l|}{ Plasma } \\
\hline $\mathrm{Na}^{+}(\mathrm{mM})$ & $152.3 \pm 2.7$ & $152.1 \pm 3.2$ & $153.0 \pm 3.0$ & $152.4 \pm 3.6$ & $153.5 \pm 3.3$ & $153.3 \pm 3.8$ & $153.4 \pm 3.9$ & $152.8 \pm 3.2$ \\
\hline $\mathrm{K}^{+}(\mathrm{mM})$ & $4.1 \pm 0.3$ & $3.7 \pm 0.4$ & $3.7 \pm 0.4$ & $3.7 \pm 0.4$ & $3.5 \pm 0.4$ & $3.4 \pm 0.3$ & $3.4 \pm 0.3$ & $3.9 \pm 0.4$ \\
\hline Calcium (mM) & $2.65 \pm 0.16$ & $2.59 \pm 0.16$ & $2.42 \pm 0.13^{*}$ & $2.34 \pm 0.10^{*}$ & $2.25 \pm 0.06$ & $2.20 \pm 0.04$ & $2.16 \pm 0.05$ & $2.22 \pm 0.14^{*}$ \\
\hline $\begin{array}{l}\text { Bupivacaine } \\
\left(\mu \mathrm{g} \cdot \mathrm{mL}^{-1}\right)\end{array}$ & 0 & $9.2 \pm 4.0^{\star} \dagger$ & $10.5 \pm 4.5^{*}$ & $10.0 \pm 3.2^{*}$ & $14.1 \pm 9.1$ & $12.8 \pm 4.4$ & $14.7 \pm 3.8$ & $20.2 \pm 7.5^{*}$ \\
\hline \multicolumn{9}{|l|}{$E C G$} \\
\hline $\mathrm{PR}(\mathrm{msec})$ & $93 \pm 16$ & $110 \pm 24^{*} \dagger$ & $123 \pm 22^{*} \dagger$ & $134 \pm 21^{*}$ & $137 \pm 18$ & $146 \pm 17$ & $153 \pm 12$ & $156 \pm 14^{*}$ \\
\hline QRS (msec) & $57 \pm 10$ & $66 \pm 12^{*} \dagger$ & $78 \pm 13^{*} \dagger$ & $90 \pm 16^{*} \dagger$ & $98 \pm 17$ & $107 \pm 20$ & $111 \pm 19$ & $119 \pm 16^{*}$ \\
\hline QTc (msec) & $327 \pm 27$ & $347 \pm 30^{*} \dagger$ & $369 \pm 31^{*} \dagger$ & $378 \pm 18^{*}$ & $390 \pm 27$ & $395 \pm 41$ & $414 \pm 30$ & $412 \pm 22^{*}$ \\
\hline
\end{tabular}

Values are expressed as mean $\pm \mathrm{SD}$. BIE $=$ end of bupivacaine infusion. The comparisons were omitted when a dog reached BIE, resulting in a number of dogs less than eight $(n=6, n=4)$ and data $(n<4)$ are not presented. ${ }^{*} P<0.05$ vs baseline; $\dagger P<0.05$ vs previous value.

oxymetry method (ABL ${ }^{\mathrm{TM}}$ 520, Radiometer, Copenhagen, Germany) at the same times to compare $\mathrm{SvO}_{2}$ and $\mathrm{cSvO}_{2}$. Blood samples for bupivacaine concentration assay were centrifuged at $2500 \mathrm{rpm}$ for 15 min to collect the plasma, which was then stored at $20^{\circ} \mathrm{C}$ until required for analysis. The bupivacaine concentration was measured by high-performance liquid chromatography.

We compared changes with baseline values at tenminute intervals. The comparison was omitted when a dog reached $\mathrm{BIE}(\mathrm{MBP} \leq 40 \mathrm{mmHg})$, resulting in a number of animals less than eight. Analysis of variance for repeated measures was used to evaluate changes over time. Linear regression analyses of $\mathrm{CO} v s \mathrm{CSvO}_{2}$, and $\mathrm{CO} v \boldsymbol{s} \mathrm{MBP}$ were recorded for the early and late periods. The linear regression plots for each period were analyzed and compared by $\mathrm{t}$ test. Linear regression analysis between $\mathrm{SvO}_{2}$ and $\mathrm{cSvO}_{2}$ was performed using the data from five dogs. Data are expressed as means \pm SD. A $P$ value $<0.05$ was accepted as significant.

\section{Results}

The amount of bupivacaine administered before reaching BIE was $29 \pm 10 \mathrm{mg} \cdot \mathrm{kg}^{-1}$, and it took $57 \pm 19 \mathrm{~min}$ for the MBP to decrease to $40 \mathrm{mmHg}$. The hemoglobin concentration at baseline was $8.7 \pm 1.1 \mathrm{~g} \cdot \mathrm{dL}^{-1}$. 


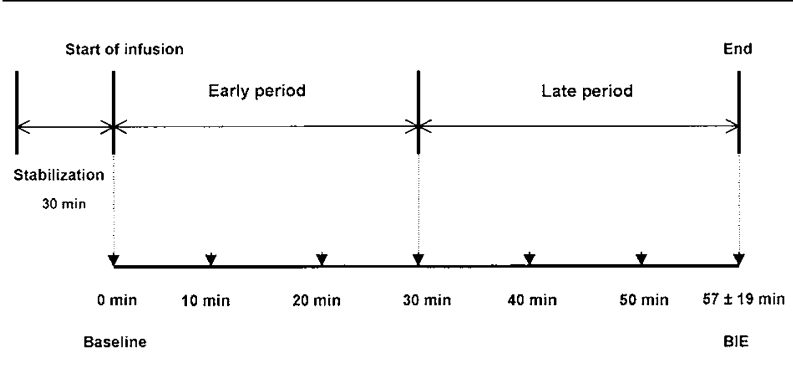

FIGURE 1 Time sequence of the experiment. BIE (end of bupivacaine infusion). Arrow $=$ blood sampling and measurement of cardiac ouput, mean arterial blood pressure and continuous mixed venous oxygen saturation.

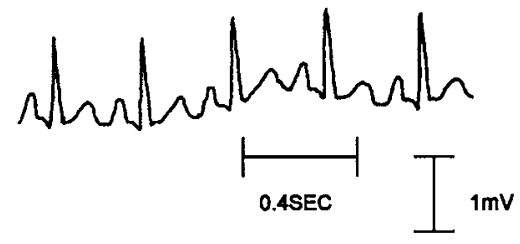

BIE

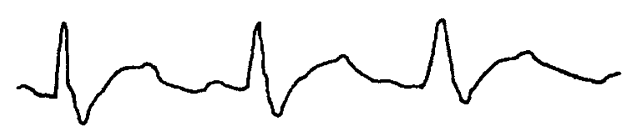

FIGURE 2 Electrocardiographic changes (lead II) induced by bupivacaine infusion. In one of the experimental dogs, during the baseline period, the values were: heart rate, 150 beats $\mathrm{min}^{-1}$; PR interval, $90 \mathrm{msec}$; QRS duration, $65 \mathrm{msec}$; and QTc interval, 320 msec. Bupivacaine administration at a concentration of 20.2 $\mu \mathrm{g} \cdot \mathrm{mL}^{-1}$ at BIE (end of bupivacaine infusion) resulted in the following alterations: heart rate, 72 beats. $\mathrm{min}^{-1}$; PR interval, 180 msec; QRS duration, $160 \mathrm{msec}$; and QTc interval $400 \mathrm{msec}$.

The bupivacaine infusion produced a decrease of $\mathrm{cSvO}_{2}$ and $\mathrm{CO}$ from baseline values ten minutes after the infusion started. No significant changes in MBP occurred during the first $30 \mathrm{~min}$ after the initiation of the bupivacaine infusion. HR began to decrease from baseline value at ten minutes. PCWP and SVR increased from their baseline values after $20 \mathrm{~min} . \mathrm{DO}_{2}$ was lower than the baseline value after ten minutes, but $\mathrm{VO}_{2}$ remained constant throughout the experiment. There were significant differences in $\mathrm{MBP}, \mathrm{HR}, \mathrm{CO}, \mathrm{cSvO}_{2}$, PCWP, CVP, SVR and $\mathrm{DO}_{2}$ at baseline and at BIE (Table I). pH, $\mathrm{PaCO}_{2}$, and $\mathrm{PaO}_{2}$ remained in the physiologic range throughout the experimental period. No statistical differences in serum $\mathrm{Na}^{+}$, or $\mathrm{K}^{+}$were found. Serum calcium concentration differed significantly from

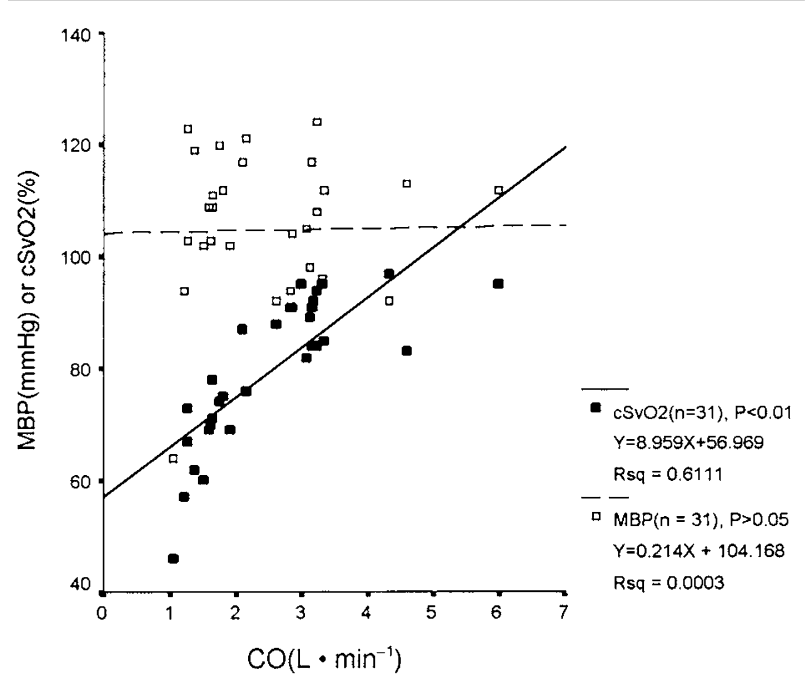

FIGURE 3 Relationship between cardiac output (CO) vs continuous mixed venous saturation $\left(\mathrm{CSvO}_{2}\right)$ or mean arterial blood pressure (MBP) in the early period. These two plots were statistically different from each other in terms of slope and intercept. Rsq $=r^{2}$.

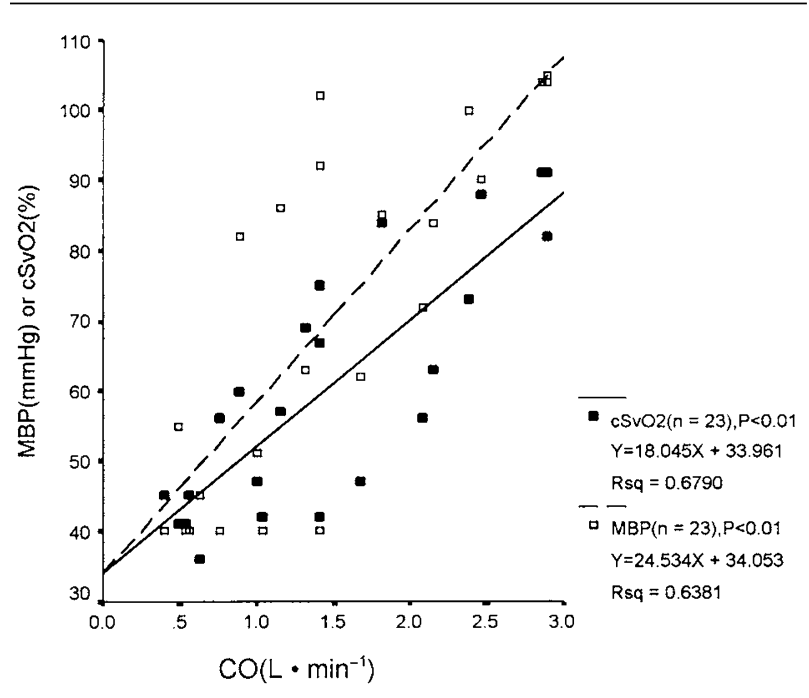

FIGURE 4 Relationship between cardiac output (CO) vs continuous mixed venous saturation $\left(\mathrm{cSvO}_{2}\right)$ or mean arterial blood pressure (MBP) in the late period. These two plots were not significantly different from each other in terms of slope and intercept. Rsq $=r^{2}$. 
baseline value after $20 \mathrm{~min}$. At BIE, the plasma bupivacaine concentration was $20.2 \pm 7.5 \mu \mathrm{g} \cdot \mathrm{mL}^{-1}$. All animals had a normal sinus rhythm before starting the bupivacaine infusion. Significant increases were seen in the PR interval, the QRS duration and the QTc interval after ten minutes (Table II). At BIE, significant changes had occurred in the PR, QRS, and the corrected QT (QTc) intervals on the ECG (Figure 2).

During the early period, $\mathrm{CSvO}_{2}$ and $\mathrm{CO}$ were linearly correlated $\left(\mathrm{r}=0.782, P=2.1 \times 10^{-7}\right)$ while MBP and $\mathrm{CO}$ were not $(\mathrm{r}=0.019, P=0.921)$. The two linear regression lines of the early period differed in terms of slope and intercept $\left(P=9.5 \times 10^{-4}, P=6.8 \times 10^{-9}\right)$ (Figure 3). During the late period, $\mathrm{cSvO}_{2}$ was correlated with $\mathrm{CO}\left(\mathrm{r}=0.824, P=1.3 \times 10^{-6}\right)$ and $\mathrm{MBP}$ correlated with $\mathrm{CO}\left(\mathrm{r}=0.799, P=4.8 \times 10^{-6}\right)$. The two linear regression plots of the late period were not significantly different in terms of slope and intercept $(P=$ $0.188, P=0.991$; Figure 4$). \mathrm{SvO}_{2}$ and $\mathrm{cSvO}_{2}$ were found to be well correlated $\left(\mathrm{r}=0.992, P=1.9 \times 10^{-17}\right)$.

\section{Discussion}

We designed this study to compare changes in $\mathrm{cSvO}_{2}$ and MBP during bupivacaine-induced cardiac depression in dogs. The results showed that $\mathrm{cSvO}_{2}$ was associated with $\mathrm{CO}$ decrease in dogs with bupivacaine-induced cardiac depression during the early stages of bupivacaine intoxication, while MBP was not. Two conditions should be satisfied for $\mathrm{CSvO}_{2}$ to be useful to monitor $\mathrm{CO}$ changes in bupivacaineinduced cardiac depression. Firstly, $\mathrm{VO}_{2}$ must be constant during monitoring, as was the case in our experiment. Secondly, there must be strong correlation between $\mathrm{SvO}_{2}$ and $\mathrm{cSvO}_{2}$, and our results show that $\mathrm{SvO}_{2}$ and $\mathrm{cSvO}_{2}$ are significantly correlated.

Both pulmonary artery catheterization and epidural anesthesia or analgesia are sometimes recommended for clinical cases such as aortic surgery, coronary artery bypass graft and thoracotomy. ${ }^{10-14}$ For such cases, $\mathrm{CSvO}_{2}$ can be a useful monitor. In the absence of a pulmonary artery catheter, the arterial lactate variation, end-tidal $\mathrm{CO}_{2}$ and ECG changes may be useful variables for detecting the cardiac toxicity of bupivacaine. ${ }^{16-18}$ In this study, we compared $\mathrm{cSvO}_{2}$ and $\mathrm{MBP}$ because $\mathrm{CO}$ is directly related to these variables. Though the experimental setting of fixed bupivacaine infusion may not represent an accidental bolus $i v$ injection, it can be useful to analyze the early changes associated with hemodynamic and cardiovascular toxicity.

Bupivacaine is a potent and long acting local anesthetic and, if accidentally injected into the systemic circulation, it can cause lethal cardiotoxic effects. Moreover, the cardiotoxic effect of bupivacaine is enhanced by hyperkalemia-induced blocking of the inward sodium current. ${ }^{19}$ Therefore, we maintained serum potassium levels within a normal range. In addition, bupivacaine is known to inhibit $\mathrm{Ca}^{2+}$ release from the sarcoplasmic reticulum. ${ }^{3}$ Although the serum calcium concentration changed significantly $20 \mathrm{~min}$ after bupivacaine administration in this experiment, the observed decrease probably had little effect on decreased $\mathrm{CO}$ because serum calcium was maintained within the normal range. Acidosis is known to be associated with increased levels of free forms of bupivacaine and thus to increase cardiotoxicity. ${ }^{20}$ Therefore, we infused sodium bicarbonate to maintain the arterial $\mathrm{pH}$ within the normal range.

In this study, cardiovascular collapse was defined hemodynamically as a MBP of $40 \mathrm{mmHg}$. We intended to induce a severe but recoverable cardiovascular collapse to allow observation of the hemodynamic changes in severe bupivacaine-induced cardiac depression. Cho et al. demonstrated that control dogs recovered spontaneously after MBP had been reduced to $65 \mathrm{mmHg}$ by a bupivacaine infusion for an average of $30 \mathrm{~min} .{ }^{21}$ Epinephrine treatment allowed the recovery of half of the dogs with bupivacaine-induced cardiac depression, which had a MBP of less than $40 \mathrm{mmHg} .^{22}$ Pilot studies showed that no dog recovered from bupivacaineinduced cardiac depression in two dogs with MBPs of $40 \mathrm{mmHg}$ in the presence of acidosis and hypothermia. However, we succeeded in resuscitating all eight dogs with epinephrine when arterial $\mathrm{pH}$ was maintained normal after severe cardiovascular collapse.

We analyzed results during the early (baseline - 30 min of infusion) and late $(30 \mathrm{~min}$ - BIE) periods of bupivacaine infusion. The early period represents the time during which spontaneous recovery is thought to be possible when the infusion of bupivacaine is stopped. ${ }^{21}$ The results showed that MBP was poorly correlated with decreased $\mathrm{CO}$ in the early period. However, in contrast to $\mathrm{MBP}, \mathrm{cSvO}_{2}$ was well correlated with $\mathrm{CO}$ during the early period. The late period represents times close to impending cardiovascular collapse. In the late period, bupivacaine caused a significant decrease in MBP. Thus, a decrease in MBP means that bupivacaine overdose has already occurred. ${ }^{22}$

The mechanism responsible for the maintenance of MBP in the early period is not clear. Increased SVR could be suggested as one of the causes. Jorfeldt et $a l .^{23}$ showed a $20-40 \%$ increase in systemic resistance in humans at a plasma bupivacaine concentration of 2 $\mu \mathrm{g} \cdot \mathrm{mL}^{-1}$. Although SVR increased during the early administration of bupivacaine, this might not persist during impending cardiovascular collapse since tissue hypoxia tends to cause arterial vasodilatation..$^{24,25}$ 
In conclusion, $\mathrm{MBP}$ is not an appropriate monitor of early bupivacaine toxicity in dogs. If the same applies to the human situation, a stable MBP may give the clinician a false sense of security during early bupivacaine toxicity. Our results show that $\mathrm{cSvO}_{2}$ is superior to $\mathrm{MBP}$ for monitoring decreased $\mathrm{CO}$, regardless of the amount of bupivacaine infusion, especially in the early period. A profound reduction of $\mathrm{CO}$ is expected when the MBP begins to decrease during the late period of bupivacaine-induced cardiotoxicity.

\section{References}

1 Clarkson CW, Hondeghem LM. Mechanism for bupivacaine depression of cardiac conduction: fast block of sodium channels during the action potential with slow recovery from block during diastole. Anesthesiology 1985; 62: 396-405.

2 Castle NA. Bupivacaine inhibits the transient outward $\mathrm{K}^{+}$current but not the inward rectifier in rat ventricular myocytes. J Pharmacol Exp Ther 1990; 255: 1038-46.

3 Lynch C. Depression of myocardial contractility in vitro by bupivacaine, etidocaine, and lidocaine. Anesth Analg 1986; 65: 551-9.

4 Long WB, Rosenblum S, Grady IP. Successful resuscitation of bupivacaine-induced cardiac arrest using cardiopulmonary bypass. Anesth Analg 1989; 69: 403-6.

5 Feldman HS, Arthur GR, Pitkanen M, Hurley R, Doucette AM, Covino BG. Treatment of acute systemic toxicity after the rapid intravenous injection of ropivacaine and bupivacaine in the conscious dog. Anesth Analg 1991; 73: 373-84.

6 Scott DB, Lee A, Fagan D, Bowler GM, Bloomfield P, Lundh $R$. Acute toxicity of ropivacaine compared with that of bupivacaine. Anesth Analg 1989; 69: 563-9.

7 Knudsen K, Beckman Suurkula M, Blomberg S, Sjovall $J$, Evardsson N. Central nervous and cardiovascular effects of i.v. infusions of ropivacaine, bupivacaine and placebo in volunteers. Br J Anaesth 1997; 78: 507-14.

8 Leach RM, Treacher DF. The relationship between oxygen delivery and consumption. Dis Mon 1994; 40: 301-68.

9 Shibutani K, Komatsu T, Kubal K, Sanchala V, Kumar $V$, Bizzarri $D V$. Critical level of oxygen delivery in anesthetized man. Crit Care Med 1983; 11: 640-3.

10 Ammar AD. Postoperative epidural analgesia following abdominal aortic surgery: do the benefits justify the costs? Ann Vasc Surg 1998; 12: 359-63.

11 Seeling W, Abnefeld FW, Rosenberg G, Heinrich H, Spilker D. Aortofemoral bifurcation bypass--effect of anesthesia procedure (NLA, thoracic continuous catheter peridural anesthesia) on circulation, respiration and metabolism. Intraoperative circulatory reactions (German). Anaesthesist 1985; 34: 217-28.
12 Stone WM, Larson JS, Young M, Weaver AL, Lunn JJ. Early extubation after abdominal aortic reconstruction. J Cardiothorac Vasc Anesth 1998;12: 174-6.

13 Kessler P, Neidhart G, Bremerich DH, et al. High thoracic epidural anesthesia for coronary artery bypass grafting using two different surgical approaches in conscious patients. Anesth Analg 2002; 95: 791-7.

14 Tanaka K, Harada T, Dan K. Low-dose thoracic epidural anesthesia induces discrete thoracic anesthesia without reduction in cardiac output. Reg Anesth 1991; 16: 318-21.

15 Van de Water A, Verheyen J, Xhonneux R, Reneman $R S$. An improved method to correct the QT interval of electrocardiogram for changes in heart rate. J

Pharmacol Methods 1989; 22: 207-17.

16 Rao V, Ivanov J, Weisel RD, Cohen G, Borger MA, Mickle $D A$. Lactate release during reperfusion predicts low cardiac output syndrome after coronary bypass surgery. Ann Thorac Surg 2001; 71: 1925-30.

17 Gudipati CV, Weil MH, Bisera J, Deshmukh HG, Rackow EC. Expired carbon dioxide: a noninvasive monitor of cardiopulmonary resuscitation. Circulation 1988; 77: 234-9.

18 Morrison SG, Dominguez JJ, Frascarolo P, Reiz S. A comparison of the electrocardiographic cardiotoxic effects of racemic bupivacaine, levobupivacaine, and ropivacaine in anesthetized swine. Anesth Analg 2000; 90: 1308-14.

19 Timour Q Freysz M, Mazze R, Couzon P, Bertix L, Faucon $G$. Enhancement by hyponatremia and hyperkalemia of ventricular conduction and rhythm disorders caused by bupivacaine. Anesthesiology 1990; 72: 1051-6.

20 Gould DB, Aldrete JA. Bupivacaine cardiotoxicity in a patient with renal failure. Acta Anaesthesiol Scand 1983; 27: 18-21.

21 Cho HS, Lee JJ, Chung IS, Shin BS, Kim JA, Lee KH. Insulin reverses bupivacaine-induced cardiac depression in dogs. Anesth Analg 2000; 91: 1096-102.

22 Saitoh K, Hirabayashi $\Upsilon$, Shimizu R, Fukuda H. Amrinone is superior to epinephrine in reversing bupivacaine-induced cardiovascular depression in sevofluraneanesthetized dogs. Anesthesiology 1995; 83: 127-33.

23 Jorfeldt L, Lofstrom B, Pernow B, Persson B, Wabren J, Widman B. The effect of local anesthetics on the central circulation and respiration in man and dog. Acta Anaesthesiol Scand 1968; 12: 153-69.

24 Edmunds NJ, Marshall JM. Vasodilatation, oxygen delivery and oxygen consumption in rat hindlimb during systemic hypoxia: role sof nitric oxide. J Physiol 2001; 532: 251-9.

25 Otter D, Austin C. Mechanisms of hypoxic vasodilatation of isolated rat mesenteric arteries. a comparison with metabolic inhibition. J Physiol 1999; 516: 249-59. 